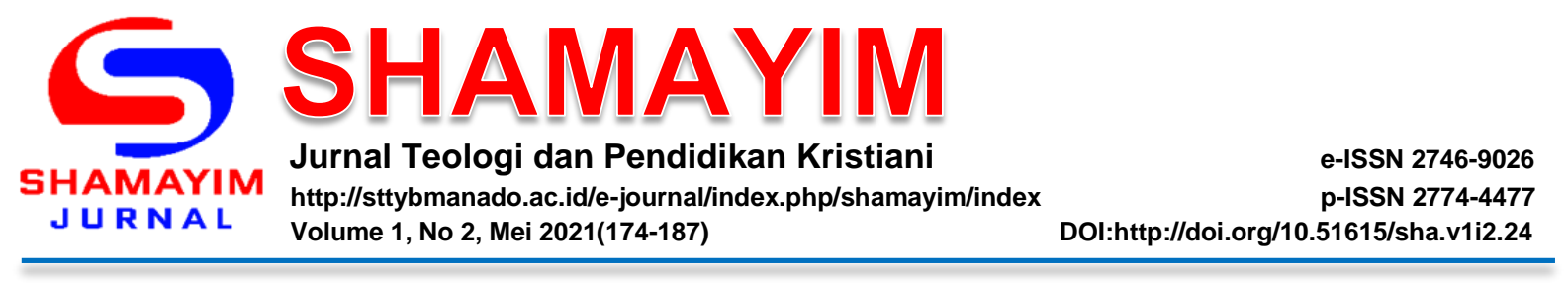

Peran Integrasi Teologi Psikologi Terhadap Pemulihan Perilaku Menyimpang

The Role of Psychological Theology Integration Against Deviating Behavior Recovery

\title{
Joko Santoso
}

Sekolah Tinggi Teologi Nazarene Indonesia Yogjakarta

joko@sttni.ac.id

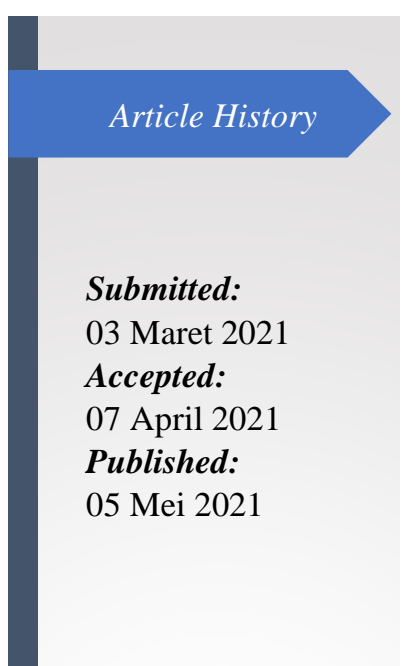

Keywords:

Role, Integration,

Theology-

Psychology,

Deviation

Behavior,

Recovery

\section{Abstract}

Humans were created in the image of God. Have a perfect personality. However, human perfection does not guarantee that humans are free from deviant behavior. This is evidenced by the biblical figures, namely Adam and Eve, deviating from God's law. Using literature studies in a qualitative descriptive approach. Thus, it can prove that theology is the foundation for everything related to humans and psychology which contributes according to their needs. Although the theological and psychological aspects have different roles and roles in handling patients, the integration of these two aspects certainly has a big impact on achieving expectations in behavioral problem.

\section{Kata Kunci:}

Peran, Integrasi, Teologi-Psikologi, Perilaku Penyimpangan, Pemulihan

\begin{abstract}
Abstrak
Manusia diciptakan segambar dengan Allah. Memiliki kepribadian yang sempurna. Namun kesempurnaan yang dimiliki manusia tidak menjamin manusia bebas dari perilaku menyimpang. Hal ini dibuktikan melalui tokoh Alkitab yaitu Adam dan Hawa menyimpang terhadap hukum Allah. Menggunakan studi literatur dalam pendekatan deskriptif kualitatif. Dengan demikian dapat disimpulkan bahwa teologi sebagai dasar fondasi atas segala sesuatu yang berhubungan dengan manusia dan psikologi memberikan kontribusi sesuai dengan kebutuhannya. Walaupun aspek teologis dan aspek psikologi memiliki peran yang berbeda satu dengan yang lain dan penanganan terhadap pasien, namun dengan terintregrasinya kedua aspek tersebut tentunya sangat memberikan dampak besar untuk meraih harapan dalam menyelesaikan persoalan penyimpangan perilaku.
\end{abstract}




\section{Pendahuluan}

Perjalanan sejarah peradaban manusia terlukiskan pada fakta sejarah dari sejak awal manusia diciptakan hingga sampai sekarang ini. Lukisan yang terpampang adalah tingkah laku manusia yang mencerminkan adanya perbuatan dan tindakan yang membuahkan perilaku menyimpang dari tatanan hidup yang digariskan oleh Tuhan sang pencipta. Penyimpangan demi penyimpangan terjadi semakin menunjukkan kerusakan kepribadian individu setiap manusia. Bahkan berdampak pada sesama dan alam semesta serta isinya. Usaha dan upaya untuk perbaikan tentunya sudah dikerjakan dengan berbagai cara, pola dan strategi. Namun, nampaknya usaha yang telah dikerjakan masih jauh dari yang diharapkan. Meskipun manusia mempunyai sifat yang mulia dari Tuhan, tetapi telah gagal melakukan tanggungjawab terhadap semua ciptaan Tuhan. Manusia tidak memposisikan diri sebagai mahluk sosial yang saling melindungi dan menyayangi.

Sejarah manusia diawali oleh Adam dan Hawa. Adam adalah manusia pertama yang diciptakan Tuhan. Tujuan penciptaan dengan jelas tercatat dalam kitab Kejadian 1: 26-28, di mana Tuhan memberi mandat, beranak cucu dan penuhi bumi. Menaklukkan dan menguasai bumi serta isinya. Namun manusia yang diciptakan memiliki gambar Allah dan dalam kesempurnaan, telah dengan sadar melakukan tindakan pelanggaran terhadap hukum Tuhan. Kegagalan yang dilakukan Adam dan Hawa menjadi wujud nyata tindakan yang merusak gambar Allah dalam dirinya, akibat menggunakan hak bebas yang diberikan Tuhan kepadanya. Tindakan tersebut tercatat dalam kitab Kejadian 3:1-24. ${ }^{1}$ Diceritakan bahwa manusia sedang berjalan-jalan di Taman Eden. Datanglah iblis dan bercakap-cakap dengan Hawa. Isi percakapan tersebut tentang pohon yang ada ditengah-tengah Taman, buahnya tidak boleh dimakan. Ini adalah larangan keras yang ditetapkan Tuhan, karena akan menyebabkan kematian. Perbincangan antara Hawa dan iblis merupakan awal terjadinya tragedi dan bencana bagi Adam dan Hawa beserta dengan keturunannya. Setan berbicara dengannya, namun, melalui catatan di Kejadian 3:1-6 ini dapat disimpulkan bahwa Hawa memang sedang berjalan sendirian di Taman Eden. Nampaknya Adam saat itu tidak berada saat Hawa sedang bercakap capak dengan iblis. Semestinya Adam melindungi dan menghalangi Hawa menerima bujukan iblis untuk makan buah pengetahuan baik dan jahat tersebut. Jadi, jelaslah bahwa sesungguhnya Allah tidak memberikan kesempatan pada dosa di Taman Eden, tetapi memberikan kesempatan pada manusia untuk "memilih" menjadi taat atau tidak taat kepada-Nya. Dan ketika manusia memilih untuk tidak taat, maka dosa masuk ke dalam dunia. Salah satu arti dari dosa adalah ketidaktaatan atau menyimpang dari perintah Tuhan $^{2}$

Menyingkapi kebutuhan integrasi kedua ilmu tersebut dalam pemulihan perilaku menyimpang, maka peneliti melakukan penyelidikan studi literatur dari Alkitab dan sumbersumber lainnya; terutama yang berkaitan dengan asal mula manusia diciptakan dan mengalami kejatuhan dalam dosa penyimpangan terhadap perintah Tuhan. Adapun yang

1 Yonatan Sumarto, “"'Suatu Tinjauan Terhadap Kejatuhan Manusia Ke Dalam Dosa Berdasarkan Kejadian Pasal 3," Jurna Pasca Sarjana Nassakke (2021): 89-97.

${ }^{2}$ Yanjumseby Yeverson Manafe, "Keberdosaan Manusia Menurut Alkitab," Jurnal Scripta Teologi dan Pelayanan Kontekstual Vol.4, No. (2019): 111-131,. 
peneliti temukan adalah: 1) Pandangan tentang manusia menurut Alkitab, 2) Pandangan konsep manusia tentang: a) Manusia dan kehendak bebas dan b) Kepribadian diri manusia. Selanjutnya dilakukan tindakan tentang: 1) bagaimana pemulihan kepribadian manusia dilakukan, 2) Mencari kenapa manusia dapat melakukan penyimpangan perilaku. 3) menemukan solusi pemecahan masalah penyimpangan perilaku. 4) Dan akhirnya melakukan tahapan penemuan masalah penyimpangan masalah perilaku dan penyelesaian masalah penyimpangan perilaku.

Hal ini sangat menarik untuk diungkap dan ditemukan apa yang sesungguhnya terjadi. Berdasarkan penemuan atas tragedi tersebut dapat memberi informasi latar belakang terjadinya penyimpangan perilaku manusia. Dengan harapan dapat memberi pembelajaran bagi umat manusia dalam mengatasi dan mencari solusi saat menghadapi situasi dan kondisi yang dapat menarik manusia terjerumus kedalam penyimpangan atas hukum-hukum Tuhan. Dengan tujuan, manusia dapat belajar dengan sejarah jatuhnya Adam dan Hawa. Secara teologis manusia membangun kesadaran pentingnya memiliki kepribadian ilahi dan kedewasaaan rohani. Menjalani kehidupan ini dalam ketundukan atas otoritas Tuhan dan hidup dalam ketaatan terhadap ketetapan-ketetapan Tuhan yang membawa keselamatan. Sedangkan secara psikologis, manusia membangun kesadaran dalam pola pikir, sikap, perilaku dan tindakan. Sehingga dengan arif dan bijak membawa dirinya hidup benar dan selaras dengan norma dan nilai hidup yang sesuai dengan kebenaran Alkitab.

\section{Metode Penelitian}

Penelitian dalam artikel ini menggunakan metode penelitian studi literatur dengan pendekatan kualitatif yang bersifat deskriptif. Sebab cenderung menggunakan analisis dengan pendekatan induktif, yaitu data yang diperoleh dengan menggunakan data, kata atau gambar $^{3}$. Penulis melakukan kajian terhadap sumber-sumber pustaka lalu menguraikannya dalam sebuah Integrasi Teologi dan psikologi dalam prinsip pemulihan perilaku menyimpang. Selanjutnya sebagai landasan pijakan dalam penanganan pemulihan perilaku menyimpang memakai Alkitab sebagai sumber utama dan sedangkan buku-buku dan literatur lainnya yang relevan menjadi pendukung guna melengkapi pendapat yang relewan dengan topik. Penulis juga menggunakan berbagai kajian dari sumber-sumber acuan yang dapat melengkapi artikel penelitian ini yang masih dianggap menjadi pendukung artikel ini. Selain itu, penulis menggunakan dan merujuk dari berbagai sumber jurnal dalam mendeskripsikan tujuan penulisan tentang peran integrasi teologi psikologi terhadap pemulihan prilaku menyimpang.

\section{Hasil dan Pembahasan}

\section{Peran Integrasi Teologi Dan Psikologi}

Kata "peran" adalah kata yang mempunyai makna suatu seperangkat alat yang digunakan untuk melakukan pekerjaan sesuai dengan kedudukan yang dimiliki. Peran tersebut merupakan tanggung jawab utama yang harus dikerjakan. ${ }^{4}$ Istilah "peran" sering

\footnotetext{
${ }^{3}$ Eko Sugiarto, Menyusun Proposal Penelitian Skrepsi Dan Tesis, Pertama. (Yogyakarta, 2015).

${ }^{4}$ Team Balai Pustaka, Kamus Besar Bahasa Indonesia, 3rd ed. (Jakarta: Balai Pustaka Departemen
} 
dipahami sebagai tugas pekerjaan yang berhubungan dengan kedudukannya yang dimiliki. Banyak pendapat menyatakan bahwa peran selalu dihubungkan dengan posisi atau jabatan yang dimiliki orang tersebut. Teologi adalah istilah dari kata Yunani, yang terdiri dari dua kata yaitu "theos" yang berarti "Tuhan/Allah", dan "logos" yang berarti "perkataan/firman/wacana." Ensycklopedia Everyman's menjelaskan, bahwa Teologi adalah: Religious knowledge, therefore, deals with God, and humans have a relationship with God (ilmu tentang agama karena berurusan dengan Sang Pencipta dan manusia hubungannya dengan Allah) ${ }^{6}$. Menurut KBBI menjelaskan bahwa teologi adalah ilmu yang berbicara tentang Tuhan, yaitu sifat-sifat Tuhan, dasar keimanan terhadap Tuhan dan agama, yang dilandasi dengan firman Tuhan dalam Alkitab ${ }^{7}$ dengan kata lain, teologi merupakan usaha untuk memberikan penjelasan tentang Allah dan karya-Nya yang bersumber dan diperoleh dari Alkitab. Sebagaimana Millard J. Erikson mendefinisikan istilah teologi merupakan pembelajaran yang focus pada penyingkapan-penyingkapan secara logis tentang pengajaran iman Kristen berdasarkan Alkitab. ${ }^{8}$

Psikologi, diambil dari bahasa Yunani kata "Psyche" dan "logos". Secara etimologis "Psyche" berarti jiwa, roh, sukma atau nafas hidup. Dan "logos" berarti ilmu pengetahuan atau studi. ${ }^{9}$ Selanjutnya psikologis sebagai ilmu memiliki obyek yang tidak dapat dibuktikan dengan indera sehingga tidak mempunyai kebenaran mutlak. Sesuatu yang tidak dapat dilihat, diraba, atau didengar. ${ }^{10}$ Maka penulis menyimpulkan, bahwa psikologi merupakan ilmu yang mengungkap tentang jiwa manusia yang abstrak atau tak terlihat dengan cara mempelajari dari sikap dan perilakunya. Tingkah laku ini kadangkala sifatnya terbuka atau umum, kadangkala tersembunyi, samar-samar.

Integrasi diambil dari kata bahasa Inggris "integration" artinya adalah kesempurnaan atau sepenuhnya. Ketika Integrasi ini berhubungan dengan aspek norma atau nilai, maka dimaknai sebagai suatu perpaduan antara unsur pandangan, pemikiran, dan pemahaman yang berbeda menjadi satu kesatuan yang utuh. ${ }^{11}$ Paul Gunadi mengutip tulisan karya Outler disadur oleh V.C. Grounds dalam bukunya Psychiatry and the Christian Massage yang menyatakan, bahwa teologi dan psikologi mempunyai beberapa kesamaan, antara lain : a). Mempunyai perhatian yang tinggi pada persolan manusia, b). Memiliki pemahaman tentang kehidupan manusia yang membutuhkan proses dalam pertumbuhannya secara dinamis menuju kedewasaan yang sejati, c) Berurusan dengan kepribadian dan karakter manusia. ${ }^{12}$

\footnotetext{
Pendidikan Nasional, 2003).

${ }^{5}$ B.F. Drewes, Apa Itu Teologi? (Jakarta: BPK Gunung Mulia, 2007), 16.

${ }^{6} \mathrm{http}: / /$ repository.uinib.ac.id/1499/4/BAB\%20III.pdf

7 "Arti Kata Teologi - Kamus Besar Bahasa Indonesia (KBBI) Online."

${ }^{8}$ Millard J. Erikson, Teologi Kristen (Malang: Gandum Mas, 2012).

${ }^{9}$ Rima Mustika, "Psikologi Klinis, Profesi Yang Menarik Untuk Masa Depanmu," Psikologi Klinis, Profesi Yang Menarik Untuk Masa Depanmu (March 2020).

${ }^{10}$ Karel Karsten Himawan, Integrating Psychology \& Christianity: The Enrichment Model (Malang: Gandum Mas, 2014), 29-30.

${ }^{11}$ Sherly Mudak, "Integrasi Teologi Dan Psikologi Dalam Pelayanan Pastoral Konseling Kristen," Missio Ecclesiae 3, no. 2 (2014): 128.

12 Paul Gunadi, "Mencermati Perjalanan Integrasi Psikologi Dan Teologi: Lajang, Nikah, Cerai?" (2002).
} 
Dengan demikian, terdapat potensi teologi dan psikologi berkolaborasi dalam menangani problematika kehidupan manusia.

\section{Kebutuhan Integrasi}

Integrasi antara teologi dan psikologi menjadi perdebatan para teolog Kristen. Hal ini dijadikan polemik oleh karena dipandang sebagai usaha yang sia-sia, karena masing-masing memiliki cara pandang yang berbeda. Teologi menggunakan Alkitab sebagai satu-satunya sumber pedoman/landasan hidup, sedangkan psikologi berasal dari filsafat hasil dari pikiran manusia belaka. Karena itu dianggap tidak sejalan dan saling bertentangan. Adapun perbedaannya tersebut Antara lain: pertama, sistem penilaiannya berbeda, kedua, psikologi adalah ilmu pengetahuan, sedangkan teologi adalah sistem keagamaan. Dengan demikian, dalam mengintegrasikan teologi dan psikologi menjadi hal yang tidak sejalan atau saling bertolak belakang. ${ }^{13}$ Pendapat Don Welch yang disadur oleh Necodimus Yuliastomo dalam artikelnya mengatakan: "Theology is our knowledge and knowledge of the person of God and "describes systematically Christian beliefs. And understanding of God is obtained from the revealed Bible as well as from the deeds of God by the Holy Spirit. Therefore, this understanding is one's personal experience. It is obtained only by do and apply properly so as to know the person of God and acknowledge his existence in God Psyhology is another aspect that is a scientific approach to recognizing human existence. This aspect tries to identify what makes humans feel, think, and act in certain patterns, thus answering questions psychologically what is obtained through the five senses or empirical evidence and analysis using rational thinking " (Teologi adalah pengetahuan dan pengetahuan kita tentang pribadi Tuhan dan "menjelaskan secara sistematis tentang kepercayaan Kristen. Dan pemahaman tentang Tuhan diperoleh dari Alkitab yang diwahyukan dan juga dari perbuatan Tuhan oleh Roh Kudus. Oleh karena itu, pemahaman ini adalah pengalaman pribadi seseorang. diperoleh hanya dengan melakukan dan menerapkan dengan benar sehingga mengenal pribadi Tuhan dan mengakui keberadaannya di dalam Tuhan. Psikologi adalah aspek lain yaitu pendekatan ilmiah untuk mengenali keberadaan manusia. Aspek ini mencoba untuk mengidentifikasi apa yang membuat manusia merasakan, berpikir, dan bertindak dalam pola tertentu, sehingga menjawab pertanyaan psikologis apa yang diperoleh melalui panca indera atau bukti empiris dan analisis dengan menggunakan pemikiran rasional "14

Selanjutnya, artikelnya yang diterbitkan dalam The Journal of Psychology \& Theology (JPT) mengatakan, bahwa: integrasi psikologi dan teologi Kristen merupakan hal yang patut dipertimbangkan guna mengeksplorasi kedua disiplin ilmu ini untuk diterapkan di dalam pelayanan Kristen: baik dalam kepemimpinan, konseling dan pelayanan lainnya. ${ }^{15}$ Pertanyaan mendasar yang patut dijadikan perenungan, bahwa: teologi adalah ilmu keagamaan yang mengatur dan menuntun manusia memiliki jalan dalam membangun hubungan dengan Tuhan dan psikologi adalah ilmu yang meneliti tingkah laku manusia. Dua

\footnotetext{
${ }^{13}$ Mudak, "Integrasi Teologi Dan Psikologi Dalam Pelayanan Pastoral Konseling Kristen."

${ }^{14}$ Ibid.

15 “Journal of Psychology \& Theology - Wikipedia."
} 
disiplin ilmu ini dapat bekerja bersama-sama guna menolong kelangsungan hidup manusia dalam mencapai tujuan hidup yang sesungguhnya, tanpa memperdebatkan cara dan metode penanganannya dalam memperbaiki keberadaan manusia. Sebab yang ditangani dan menjadi obyeknya adalah sama yaitu manusia. Meski pada akhirnya, teologi menjadi pondasi dan penentu pengambilan keputusan, sedangkan psikologi sebagai pendukung untuk melengkapi pada sisi yang lain.

\section{Pandangan Tentang Manusia Menurut Alkitab}

Pertanyaan mendasar berbicara tentang manusia yaitu manusia itu sendiri. Manusia adalah mahluk yang unik dan penuh dengan misteri. Untuk menyingkapkan keberadaan manusia, maka perlu pendekatan yang dapat memberi jawaban kebutuhan mendasar manusia. Alkitab dengan jelas memberikan data secara terperinci tentang fakta penciptaan manusia, dari bahan, cara dan prosesnya. Ini adalah fakta kebenaran yang harus dipegang teguh oleh orang percaya. Werner Gitt memberi pernyataan bahwa jika menolak fakta penciptaan yang dicatat dalam Alkitab, maka akan disesatkan oleh pemikiran teori evolusi yang diciptakan oleh Darwin. ${ }^{16}$ Sung Wook Chung berpendapat, bahwa penciptaan manusia sesuai dengan gambar Allah. Adapun segambar dengan Allah tersebut mengarah pada ketiga unsur secara menyeluruh, yaitu: substantif, relasional, dan fungsional. ${ }^{17}$ Pandangan Substantif yang dimaksudkan bahwa manusia memiliki pikiran dan keinginan bebas sebagai gambar Allah. Sedangkan yang dimaksudkan dengan pandangan relasional yaitu menyatakan bahwa manusia memiliki kemampuan berelasi dengan Allah dan dengan sesamanya. Dan selanjutnya pandangan Fungsional menyatakan fungsi manusia untuk menyatakan gambar Allah melalui karya-karya-Nya.

Secara Substansi manusia memiliki warisan sifat-sifat Allah, yaitu manusia bisa menjadi bijak dalam menggunakan pikiran, menjadi kudus di dalam batinnya, dan benar di dalam perbuatannya." Secara Relasional, penciptaan manusia memancarkan sifat-sifat Allah dan menjadi mahluk sosial yang saling berkaitan secara sosial satu sama yang lainnya. Secara Fungsional, manusia mempunyai tugas dan kewajiban dalam mengelola bumi ini. Kejadian 2:7 “...ketika itulah TUHAN Allah membentuk manusia itu dari debu tanah dan menghembuskan nafas hidup ke dalam hidungnya; demikianlah manusia itu menjadi makhlukyang hidup. Berdasarkan ayat tersebut, dapat ditemukan data proses penciptaan. Allah menciptakan manusia menggunakan kata Ibrani "bana" yang diterjemahan membentuk bukan menciptakan dalam bahasa Ibrani "asah". Hal ini menunjukan bahwa manusia diciptakan melalui proses pembentukan dari debu tanah dalam bahasa Ibrani "aphar" yang berarti lumpur, kotoran. Kemudian Allah menghembuskan nafas pada pada debu yang telah dibentuk itu dan menjadi mahluk hidup. ${ }^{18}$

\footnotetext{
${ }^{16}$ Werner Gitt, Keajaiban Manusia (Jakarta: Yayasan Komunikasi Bina Kasih, 2009).

${ }^{17}$ Sung Wook Chung, Belajar Teologi Sistematika Dengan Mudah (Bandung: Visi Press, 2011).

${ }^{18} \mathrm{https}$ ://alkitab.sabda.org/verse.php?book=Kej\&chapter $=2 \&$ verse $=7$
} 


\section{Pandangan Konsep Manusia}

Manusia menjadi mahluk Tuhan yang memiliki unsur-unsur yang disebut dengan istilah "dikotomi" dan "trikotomi". Dikotomi melihat kerberadaan manusia dalam dua bagian, yaitu bagian yang terlihat (tubuh) dan bagian yang tidak kelihatan adalah roh (termasuk jiwa) ${ }^{19}$ Kelompok yang memegang paham dikotomi ini sangat terkenal sehingga faham tersebut dijadikan doktrin secara resmi diterima kalangan kekristenan sampai hari ini. Pengikut faham tersebut menggunakan landasan Alkitab dalam Kitab Kejadian 2:7 yang menjelaskan bahwa Allah menghembuskan napas sehingga manusia Adam menjadi makluk hidup. Roh dan jiwa manusia ditafsirkan bukan merupakan dua unsur yang berlainan, namun kedua istilah tersebut digunakan silih berganti oleh penulis Alkitab. Sebagai contoh: Matius. 6:25; 10:28 bahwa manusia disebut dengan istilah tubuh dan jiwa), sedangkan dalam 1 Korintus 5:3,5 (manusia disebut dengan istilah tubuh dan roh). Terdapat contoh yang lain yaitu dalam Kejadian 41:8; Mazmur 42:6; Matius 20:28; 27:50; Yohanes 12:27; Ibrani 12;23; Wahyu 6:9. Sedangkan Trikotomi dipahami bahwa manusia memiliki tiga bagian, yaitu: roh, jiwa dan tubuh. Kelompok yang mempercayai kepercayaan ini menyakini bahwa dalam diri manusia terdapat tiga unsur; yaitu: tubuh, jiwa dan roh. Kelompok yang memegang paham ini melandaskan paham tersebut pada Surat Paulus dalam I Tesalonika 5:23 dan Surat Ibrani 4:12 dengan menyatakan bahwa manusia memiliki tiga unsur. Kedua kelompok paham tersebut memiliki landasan yang kuat dengan berdasarkan bukti-bukti yang dapat dipertanggung jawabkan baik secara telogis maupun ilmu pengetahuan. ${ }^{20}$

Berdasarkan pernyataan dua paham diatas, agar dapat secara mendalam mengungkapkan keadaan diri manusia yang berkaitan dengan psikologi, penulis condong memakai paham trikotomi, supaya secara menyeluruh membedah, menemukan unsur-unsur dan menjawab kebutuhannya. Dalam Surat 1 Tesalonika 5: 23 tertulis demikian; "Semoga Allah damai sejahtera menguduskan kamu seluruhnya dan semoga roh ( $\pi v \varepsilon v \mu \alpha$, spirit), jiwa ( $\psi v \chi \eta$, soul) dan tubuhmu ( $\sigma \omega \mu \alpha$, body) terpelihara sempurna dengan tak bercacat pada kedatangan Yesus Kristus, Tuhan kita" ${ }^{21}$ Disini Rasul Paulus menjelaskan bahwa manusia memiliki keberadaan yang terdiri dari 3 unsur, yaitu: roh, jiwa dan tubuh. Sebagaimana dinyatakan manusia memiliki 3 unsur tersebut mendapatkan seluruh kebutuhannya dan sehingga terpelihara sempurna, yaitu menjadi kudus, lengkap dan tak bercela. Dengan demikian penulis menyimpulkan, bahwa penanganan kepribadian manusia harus memenuhi seluruh ketiga unsur tersebut. Ketiga unsur berhak menerima perawatan, pemeliharaan, pertumbuhan dan pendewasaan, sehingga berdiri secara tepat, benar dan terhindar dari kecemaran, dan akhirnya bertumbuh-kembang sesuai dengan tujuan dalam kesempurnaan hidup.

${ }^{19}$ Joko Santoso, "Implementasi Pelayanan Konseling Holistik Terintegrasi Aspek Teologi, Psikologi Dan Skill Konseling," Sanctum Domine: Jurnal Teologi 9, no. 2 (2020): 17-32.

${ }^{20}$ Ken L. Sarles, Introduction to Biblical Counseling (Malang: Gandum Mas, 2002), 453-455.

21 "1 Tesalonika 5:23 (Versi Paralel) - Tampilan Ayat - Alkitab SABDA." 


\section{Manusia dan Kehendak Bebas}

Berbicara tentang manusia tidak pernah ada habisnya, karena manusia itu sendiri unik dan penuh misteri. Manusia melihat keberadaannya secara utuh adalah ciptaan Tuhan, Manusia melihat keberadaannya sendiri dalam bermacam sudat pandang sesuai pemahamannya dan keimanannya, sebagaimana dinyatakan oleh para filsuf dan ilmuwan. Tidak heran para ilmuwan secara terus menerus mempelajari tentang kehidupan manusia hingga sampai pada hari ini. Sebagai makhluk yang religius, pasti menyakini bahwa manusia diciptakan oleh Tuhan Allah. Dan oleh sebab Tuhan Yang Maha Kuasa dan Maha Sempurna yang menciptakan maka tentunya dalam diri manusia ada hal-hal yang istimewa dibanding dengan mahluk ciptaan yang lain. Manusia menjadi makhluk ciptaan yang mulia, mendapat kebebasan dalam memilih, menetapkan sikap, dan melakukan tindakan. Sejak diciptakan, manusia mendapatkan kebebasan. Kebebasan untuk memilih, namun memiliki tanggung jawab terhadap pilihannya atas perbuatan dan tingkah lakunya kebebasan yang dimiliki manusia terbukti dan dicatat dalam kitab Kejadian 3. Dengan secara sadar manusia melanggar perintah Tuhan yang telah memberikan perintah agar jangan makan buah dari "Pohon pengetahuan tentang yang baik dan yang jahat" sedang buah lainnya diperbolehkan untuk dimakan. Manusia Adam dan Hawa memiliki makan buah terlarang dan akibatnya terputus hubungan dengan Tuhan dan mengalami kematian.

Kejadian 2:16-17: Lalu TUHAN Allah memberi perintah ini kepada manusia: "Semua pohon dalam taman ini boleh kau makan buahnya dengan bebas, tetapi pohon pengetahuan tentang yang baik dan yang jahat itu, janganlah kaumakan buahnya, sebab pada hari engkau memakannya, pastilah engkau mati. Hal ini menunjukkan bahwa Tuhan memang memberikan hak bebas untuk memilih peraturan untuk ditaatinya. Kehendak bebas tersebut digunakan seturut dengan pengertian dan keinginannya sendiri. Itulah sebabnya Adam dan Hawa melanggar perintah Tuhan. Kehendak bebas yang dimiliki dianggap bebas dipergunakan tanpa ada penghalang, sedangkan jelas Tuhan sudah perintahkan agar jangan makan buah itu. Ini adalah peraturan yang ditetapkan Tuhan bagi mereka. ${ }^{22}$ Hak bebas tersebut dengan jelas tercatat didalam kisah tragedi di Taman Eden. Tuhan memberikan perintah supaya jangan melanggarnya. Yaitu makan buah dari pohon yang ada ditengahtengah taman, pasti akan berakibat kematian." 23 Akibat hak dan kehendak bebas yang dimiliki itulah yang mengakibatkan manusia telah jatuh dan melakukan perbuatan yang melanggar ketetapan Tuhan. Sebagaimana telah diterangkan dalam pembahasan sebelumnya, manusia diciptakan dari debu tanah yang mengandung organik yang merupakan kekayaan alam yang terdiri dari komposisi, struktur dan tekstur, tetapi karena bersifat matrial atau bendawi maka memiliki keterbatasan.

Manusia tidak dapat melawan kodratnya sebagai ciptaan yang terbatas. Jika melampaui kodratnya, maka akan terjadi kekacauan dan kerusakan, yang berakibat fatal. Pelanggaran terhadap perintah Tuhan menjadikan manusia tidak lagi memiliki kemuliaan

${ }^{22}$ Yusak Noven Susanto, "Pandangan Teologis Tentang Kehendak Bebas Manusia Dan Relevansinya Dengan Kehidupan Orang Percaya Saat Ini," n.d.

${ }^{23}$ Tarpin Tarpin, "Pandangan Kristen Tentang Dosa: Asal Muasal Dan Cara Menebusnya," Jurnal Ushuluddin 16, no. 2 (2010): 221-233. 
dan gambar Allah. Keberadaan manusia rusak secara menyeluruh dan mengakibatkan terjadinya penyimpangan-penyimpangan perilaku yang menyentuh seluruh sendi-sendi hidup dan berdampak persoalan secara universal. ${ }^{24}$ Akibatnya secara spiritual manusia tidak dapat lagi berelasi dengan Sang Pencipta. Manusia dapat kembali berelasi dengan Tuhan, maka Tuhan memanggil manusia untuk datang kepadaNya dan menerima penebusan oleh pengorbanan Yesus Kristus di kayu salib. Secara simbolis telah Tuhan lakukan ketika ditaman Eden, dengan mengorbankan seekor domba dan menggunakan kulitnya untuk menjadi pakaian Adam dan Hawa (Kejadian 3: 21). Secara psikis/jiwani manusia mengalami disolder (gangguan kejiwaan). Agar dapat mengalami pemulihan maka dibutuhkan perubahan pola berpikir atau paradigma, agar memandang dan menyingkapi kehidupan dapat dengan sadar dan memahami secara benar dan tepat. Dan secara lahiriah mengalami kelemahan dan mudah terserang dengan berbagai-bagai penyakit. Agar dapat tetap sehat dan berguna, maka tubuh harus dipelihara dengan memiliki pola hidup sehat, sehingga dapat beraktifas dengan baik dan menghasilkan karya hidup yang memuliakan Tuhan.

\section{Kepribadian Diri Manusia}

Keberadaan manusia telah mengalami kerusakan fatal akibat pelanggaran atas ketetapan Tuhan, sebagaimana pernyataan Freud seorang pelopor psikoanalisis ${ }^{25}$, bahwa pada awalnya manusia diumpamakan sebagai gunung es yang nampak bagian ujung atas sebagai kesadaran manusia dan dibawah yang tak kelihatan adalah ketidak-sadaran manusia. Peneliti menyingkapi pernyataan tersebut diatas, berpendapat bahwa sangatlah jelas manusia tidak sepenuhnya dapat memahami seperti apakah keberadaan dirinya seutuhnya. Keterbatasan yang dimiliki manusia ketika melawan kodratnya yang telah ditetapkan Tuhan, maka berakibat kekacauan dan kerusakan. Dari sisi rohani, manusia diliputi dengan kerusakan hubungan dengan Tuhan dan sesama. Hal ini dibuktikan dengan adanya pertentangan dalam diri manusia terhadap perintah Tuhan dan perselisihan antar manusia satu dengan yang lainnya. Dalam bukunya "Teologi Kristen" Millard mengatakan, bahwa keinginan manusia itulah yang menjadi sumber dosa. Kehendaknya merupakan indikator menuju tindakan berdosa. Adapun keinginan tersebut dapat dikelompokkan dalam 3 kelompok, yaitu keinginan terhadap suatu kenikmatan diri, suatu kepemilikkan diri dan suatu kepuasan diri. ${ }^{26}$

Pemulihan jati diri manusia merupakan suatu projek sepanjang sejarah manusia. Hal ini dilakukan guna terpeliharanya keberlangsungan hidup manusia. Pada hakekatnya menurut teori hirarki Abraham Moslow ${ }^{27}$, kebutuhan manusia pemulihan jati diri manusia terdiri dari 5 kebutuhan dasar, yaitu: a) Biologis. b) Keamanan, c) Kasih, d) Sosial, e) Aktualisasi Diri, Berdasarkan kitab Kejadian 3: 1-24 Peneliti akan menggunakan perikop ini

\footnotetext{
${ }^{24}$ Santoso, "Implementasi Pelayanan Konseling Holistik Terintegrasi Aspek Teologi, Psikologi Dan Skill Konseling."

${ }^{25}$ H Syawal and Helaluddin Helaluddin, "Psikoanalisis Sigmund Freud Dan Implikasinya Dalam Pendidikan" (March, 2018).

${ }^{26}$ Millard J. Erikson, Teologi Kristen.

27 "Hirarki Kebutuhan Manusia Menurut Abraham Maslow Dalam Perspektif Alkitabiah."
} 
sebagai sumber informasi dalam menemukan jawaban kebutuhan pemulihan kepribadian diri manusia. Perikop tersebut dieksplorasi guna membangun pola pemahaman yang benar, tepat dan sesuai. Kemudian membangun prinsip-prinsip landasan berpikir yang konstruktif, obyektif dan sistematis. Selanjutnya menentukan langkah-langkah pelaksanaan pemulihan keribadian manusia agar dapat membawa dirinya hidup dalam keteraturan, kedisiplinan dan sesuai dengan ketetapan-ketetapan Tuhan.

\section{Pemulihan Kepribadian Manusia}

Allah menciptakan manusia segambar dengan-Nya. Dengan tujuan supaya manusia bisa melaksanakan mandat sosial (Kejadian 1: 26-28) dengan memelihara dan mengusahakan segala ciptaan Tuhan. Namun manusia telah menyimpang dari tujuan Tuhan dan melanggar ketetapan Tuhan. Hal ini menyebabkan kepribadian manusia menjadi rusak. Manusia kehilangan gambar Allah yang merupakan inti dari kebutuhan manusia yang sejati dan sesungguhnya. Selanjutnya, terjadinya penyimpangan yang dilakukan oleh manusia merupakan tindakan dan perilaku yang perlu diselidiki dan ditemukan. Sebenarnya apa yang menyebabkan hal itu dapat terjadi. Jika ditelisik, Adam dan Hawa sebagai manusia pertama diciptakan, tidak seharusnya menyimpang dan melanggar ketetapan Tuhan. Tetapi kenyataan berbicara lain. Adam dan Hawa memiliki gambar atau sifat Allah dapat melakukan tindakan yang bertolak belakang. Berarti ada sisi lain yang menyebabkan hal ini terjadi. Thiessen menyatakan sependapat dengan pemahaman diatas. Bahwa perbuatan Adam dan Hawa melanggar perintah Tuhan, dilakukan berdasarkan atas kesadaran oleh keinginan hati dan tanpa paksaan. ${ }^{28}$

\section{Penyimpangan Perilaku Manusia}

Menelaah tindakan penyimpangan yang dilakukan manusia pasti ada yang menyebabkan. Untuk menemukan jawaban, tentunya membutuhkan sumber-sumber autentik dan dapat dipercaya sebagai landasan berpijak. Sehingga dapat diperoleh informasi dan data-data yang dapat dipertanggung jawabkan. Penulis menyakini bahwa landasan tersebut adalah buku kuno yang inspiratif dan ditulis ribuan tahun yang lalu namun tidak pernah usang oleh waktu, yaitu Alkitab. Informasi yang ada didalamnya bukan sekedar literatur, karena berasal dari iluminasi atau pewahyuan Sang Penguasa jagat raya dan yang selalu ada disetiap jaman dan sejarah manusia. Beranjak dari sini, penulis mencoba mengeksplorasi isi kitab-kitab yang terdapat dalam Alkitab dan mencari data-data penting dalam mengungkapkan misteri dan menemukan solusi.

Inti sari dari pengajaran kristen menempatkan Alkitab adalah sumber pengetahuan. Alkitab menuntun umat mengenal Tuhan dan pengetahuan yang sejati berpusat pada Allah dan menjadikan Alkitab adalah sumbernya. ${ }^{29}$

28 Pardomuan Marbun, “Konsep Dosa Dalam Perjanjian Lama Dan Hubungannya Dengan Konsep Perjanjian," CARAKA: Jurnal Teologi Biblika dan Praktika 1, no. 1 (2020): 1-16.

${ }^{29}$ Evasari Kristiani Lase and Friska Juliana Purba, "Alkitab Sebagai Sumber Pengetahuan Sejati Dalam Pendidikan Kristen Di Sekolah Kristen: Sebuah Kajian Epistemologi,” Jurnal Abdiel: Khazanah Pemikiran Teologi, Pendidikan Agama Kristen dan Musik Gereja 4, no. 2 (2020): 149-166. 


\section{Penemuan Penyimpangan perilaku.}

Peneliti menggunakan landasan teologis dan psikologis sebagai contoh adanya penemuan masalah dalam Kitab Kejadian 3: 1-24, yaitu sebuah tragedi sejarah manusia di Taman Eden. Faktor apa yang harus digali untuk menemukan titik temu dalam proses penyelidikan untuk penyelesainnya, ${ }^{30}$ yaitu: a). Aspek Psikologis: Terjadi komunikasi/interaksi antar mereka. Komunikasi tersebut membicarakan tentang pohon dan buah yang boleh atau tidak boleh dimakan. Dalam perbincangan tersebut iblis mencoba membelokkan pemahaman tentang larangan Tuhan dengan pemikiran lain. Maka Hawa memandang itu sebagai suatu pemikiran yang masuk akan dan memberi pola pemahaman yang lain. $b$ ). Aspek Teologis: Pembicaraan antara Hawa dan iblis tentang hukum Allah yang harus ditaati. Peraturan tersebut berhubungan dengan ujian sikap Hawa terhadap Tuhan Sang Pencipta yang memiliki konsekuensi didalamnya. Adapun aspek penunjang adalah: $a$ ). Unsur Matrial: Adanya pohon pengetahuan baik dan jahat ditengah-tengah Taman Eden, yang menjadi pusat perhatian. b). Unsur Personal: Aspek ini menunjuk pada pribadi Hawa sebagai wanita dan istri Adam. Sedangkan iblis adalah mahluk lain yang menggunakan identitas seekor ular. c). Unsur Moral: Hawa sebagai seorang pribadi bersikap dan bertindak melakukan penyimpangan atas norma/nilai hukum yang diberlakukan di Taman Eden. $d$ ). Unsur Sosial: Interaksi Antara Hawa dan iblis menghasilkan suatu hubungan timbal balik.

Dalam cerita ini memberi informasi dan data temuan adanya penyimpangan pada sisi teologis yaitu pelanggaran terhadap hukum Tuhan dan pada sisi psikologis yaitu perubahan terhadap pemahaman/paradigma dari yang semestinya. Sehingga berakibat buruk pada seluruh keberadaan; Baik atas diri Hawa sendiri, Adam suaminya dan iblis. Bahkan hal ini terus berlangsung hingga sampai pada hari ini dalam sejarah hidup manusia. Tindakan melanggar perintah Tuhan bukan hanya berdampak atas Adam dan Hawa sampai kepada anak cucunya. Bernike dalam artikel jurnalnya menyebut dosa yang diwariskan. ${ }^{31}$

\section{Pemecahan dan Penyelesaian Masalah Penyimpangan Perilaku}

Data riil yang menunjukkan keberadaan diri manusia adalah, bahwa: a). Manusia diciptakan dari "debu tanah". Meski diciptakan segambar dengan Allah dan sempurna, tetapi tubuhnya memiliki keterbatasan dan kelemahan. $b$ ). Manusia mempunyai "hak bebas" dalam mengeksplorasi dirinya dalam segala hal. Manusia dapat menggunakan hak tersebut untuk memenuhi keinginannya. c). Manusia memiliki "pengetahuan yang terbatas" untuk mengetahui seluruh alam semesta dan rahasia kehidupan. Dengan keberadaan yang demikian, sangat memungkinkan manusia menciptakan permasalahan pada dirinya sendiri dan diluar dirinya.

Cara untuk mencari dan menemukan suatu pemecahan masalah, tentunya menjadi tanggung jawab setiap individu. Itulah sebabnya setiap pribadi harus berusaha dan melakukan langkah-langkah terebut diatas sebagai acuan pemecahan masalah. Sehingga

${ }^{30}$ Mudak, Sherly, Integrasi teologi dan psikologi dalam pelayanan pastoral konseling Kristen, Jurnal Missio Ecclesiae, 3 (2), 2014

${ }^{31}$ Bernike Sihombing, "Kepribadian Dan Kehidupan Hamba Tuhan Menurut 1 Timotius 3: 1-13," KURIOS (Jurnal Teologi dan Pendidikan Agama Kristen) 2, no. 1 (2018): 1-19. 
proses yang dilakukan bertalian dengan psikologis yang mengunakan pondasi teologi Kristen. Dengan demikian, aspek psikologi diterima dalam proses pemulihan dari perilaku menyimpang dan ditempatkan dibawah otoritas sepenuhnya pada Alkitab. ${ }^{32}$

Adapun dalam penyelesaian masalah penyimpangan prilaku tesebut diatas, disimpulkan sebagai berikut: Pada Aspek Psikologi adalah: a) Faktor Hak Bebas. Secara individu manusia adalah mahluk yang memiliki kebebasan untuk bersikap, berperilaku dan bertindak. Meskipun sudah mendapatkan peraturan untuk ditaati, namun kehendak bebas setiap individu mendorong melakukan pelanggaran/ penyimpangan terhadap nilai atau kaidah hidup yang normatif/kepatutan. Eden adalah Taman yang dibuat Tuhan dan dipercayakan oleh manusia untuk dikelola dan diusahakan. Tetapi manusia dengan hak bebasnya melakukan tindakan sesuai dengan keinginannya. b). Faktor Pengetahuan terbatas. Pengetahuan terbatas yang dimiliki manusia menyebabkan keingin-tahuan atas semua misteri kehidupan ini. Yang jadi catatan penting adalah mendapatkan sumber pengetahuan itu berasal dari mana. Ketika didapatkan dari sumber yang salah, maka bencana yang datang. Pengetahuan yang diperoleh dari iblis membelokkan makna atau arti yang sesungguhnya, sehingga memdapatkan pengetahuan yang menyimpang. Sedangkan pada Aspek Teologi adalah. a). Faktor Ketidak-taatan; Secara teologis, manusia dinyatakan telah melanggar ketetapan Tuhan. Pelanggaran tersebut dinamakan "dosa" dalam Bahasa Yunani "harmatia" 33 yang artinya tidak memenuhi standart Allah. Seperti seorang pemanah yang mengarahkan anak panahnya ke suatu titik tetapi selalu meleset dan tidak megenai sasaran. Karena hal ini sudah menjadi bagian dari hidup manusia, manusia akan secara terus-menerus melakukan kesalahan dan cenderung kepada perilaku menyimpang atau berbuat kejahatan dan melawan norma-norma ajaran Tuhan selama tidak ada penyelesaian. b). Faktor taburtuai: Akibat dari perbuatan dosa atau penyimpangan terhadap ketetapan Tuhan membawa dampak yang sangat serius atas keberlangsungan kehidupan manusia. Manusia menerima hukuman yaitu: Secara lahiriah akan mati; Diusir dari taman Eden dan mengalami penderitaan secara lahiriah sepanjang hidupnya. Adapun penderitaan pada wanita mengalami sakit bersalin saat melahirkan, dan pada pria harus bersusah payah bekerja untuk mencari nafkah demi memelihara hidup dan keluarganya. bahkan dalam mengatasi dan mencari solusi atas permasalahan-permasalahan. Dampak dosa dalam diri manusia begitu membuat manusia kehilangan jati dirinya yang sesungguhnya. Manusia tidak dapat mencapai Allah; manusia menjadi seteru Allah; dan manusia mengalami kematian. ${ }^{34}$ Berdasarkan penjelasan dan keterangan diatas, maka penyelesaian masalah dapat dilakukan, yaitu dengan melakukan langkah-langkah sebagai berikut: a) Penggunaan hak bebas yang dimiliki didasari oleh norma-norma atau kaidah-kaidah yang berlaku sesuai dengan kebenaran Alkitab. b). Pengembangan pengetahuan harus mendapatkan dari sumber yang benar. c). Perilaku penyimpangan karena ketidak-taatan harus dibereskan/diselesaikan dengan Tuhan d). Bangun kesadaran dan kedewasaan rohani dalam memahami sebab akibat

\footnotetext{
${ }^{32}$ Mudak, "Integrasi Teologi Dan Psikologi Dalam Pelayanan Pastoral Konseling Kristen.”

33 "Page Not Found - Suara Injil."

${ }^{34}$ Federans Randa, "Karya Keselamatan Allah Dalam Yesus Kristus Sebagai Jaminan Manusia Bebas Dari Hukuman Kekal Allah,” Logon Zoes: Jurnal Teologi, Sosial Dan Budaya 3, no. 1 (2020): 35-62.
} 
dari suatu sikap dan perbuatan, bahwa apapun yang diperbuat selalu ada konsekuensinya. Pemulihan hidup yang manusia capai mengarah pada kualitas hidup rohani dan karakter Kristus yang terjadi dari kemuliaan kepada kemuliaan sampai tertuju pada kesempurnaan. ${ }^{35}$.

\section{Kesimpulan}

Intergasi teologi dan psikologi dapat bekerja bersama dalam meneliti dan mempelajari tingkah-laku manusia; baik berkaitan dengan perilaku dan kepribadian, demikian juga berhubungan dengan kepercayaan dan perubahan karakter yang ilahi. Teologi adalah ilmu yang mempelajari tentang Tuhan Sang Pencipta alam semesta termasuk manusia didalamnya. Sedangkan psikologi adalah ilmu yang mempelajari tingkah laku manusia. Jika ditinjau dari sudut pandang Alkitab sebagai sumber kebenaran yang memberi informasi dan data mengenai keberadaan manusia (Mazmur 119: 105, 2 Tim 3: 16, Ibrani 4: 12).

Dengan demikian, Teologi sebagai dasar pondasi atas segala sesuatu yang berhubungan dengan manusia dan psikologi memberikan kontribusi sesuai dengan kebutuhannya. Kedua aspek tersebut diatas dapat berperan sesuai dengan keilmuannya dan masing-masing memakai caranya dalam menangani konseli/klien. Intregrasi kedua aspek ini bergerak sesuai tujuan yang dikehendaki dengan lebih baik sebagaimana yang diharapkan dalam menyelesaikan persoalan penyimpangan prilaku. Berdasarkan Surat 1 Tesalonika 5: 23, maka pada: a) Aspek Spiritual: Pemulihan perilaku menyimpang dapat diselesaikan dengan menerima penebusan dalam Yesus Kristus supaya menjadi manusia baru, b) Aspek Psikologi: Pemulihan perilaku menyimpang dapat diselesaikan dengan cara mengubah pola pikir agar secara sadar hidup dalam kebenaran dan norma-norma kehidupan, c) Aspek Matrial: Menjalani kehidupan dengan pola hidup sehat dan menggunakan tubuh yang sehat untuk memuliakan nama Tuhan.

\section{Daftar Pustaka}

B.F. Drewes. Apa Itu Teologi? Jakarta: BPK Gunung Mulia, 2007.

Gunadi, Paul. "Mencermati Perjalanan Integrasi Psikologi Dan Teologi: Lajang, Nikah, Cerai?" (2002).

Karel Karsten Himawan. Integrating Psychology \& Christianity: The Enrichment Model. Malang: Gandum Mas, 2014.

Ken L. Sarles. Introduction to Biblical Counseling. Malang: Gandum Mas, 2002.

Lase, Evasari Kristiani, and Friska Juliana Purba. "Alkitab Sebagai Sumber Pengetahuan Sejati Dalam Pendidikan Kristen Di Sekolah Kristen: Sebuah Kajian Epistemologi." Jurnal Abdiel: Khazanah Pemikiran Teologi, Pendidikan Agama Kristen dan Musik Gereja 4, no. 2 (2020): 149-166.

Marbun, Pardomuan. "Konsep Dosa Dalam Perjanjian Lama Dan Hubungannya Dengan Konsep Perjanjian.” CARAKA: Jurnal Teologi Biblika dan Praktika 1, no. 1 (2020): $1-16$.

35 Robinhot Nababan, "Pembaharuan Awal Pertumbuhan Menurut Efesus 4: 23," Kerussol 1, no. 1 (2018): 68 . 
Millard J. Erikson. Teologi Kristen. Malang: Gandum Mas, 2012.

Mudak, Sherly. "Integrasi Teologi Dan Psikologi Dalam Pelayanan Pastoral Konseling Kristen." Missio Ecclesiae 3, no. 2 (2014): 128.

Mustika, Rima. "Psikologi Klinis, Profesi Yang Menarik Untuk Masa Depanmu." Psikologi Klinis, Profesi Yang Menarik Untuk Masa Depanmu (March 2020).

Nababan, Robinhot. "Pembaharuan Awal Pertumbuhan Menurut Efesus 4: 23." Kerussol 1, no. 1 (2018): 10.

Randa, Federans. "Karya Keselamatan Allah Dalam Yesus Kristus Sebagai Jaminan Manusia Bebas Dari Hukuman Kekal Allah.” LOGON ZOES: Jurnal Teologi, Sosial dan Budaya 3, no. 1 (2020): 35-62.

Santoso, Joko. "Implementasi Pelayanan Konseling Holistik Terintegrasi Aspek Teologi, Psikologi Dan Skill Konseling.” SANCTUM DOMINE: JURNAL TEOLOGI 9, no. 2 (2020): 17-32.

Sihombing, Bernike. "Kepribadian Dan Kehidupan Hamba Tuhan Menurut 1 Timotius 3: 113." KURIOS (Jurnal Teologi dan Pendidikan Agama Kristen) 2, no. 1 (2018): 1-19.

Sugiarto, Eko. Menyusun Proposal Penelitian Skrepsi Dan Tesis. Pertama. Yogyakarta, 2015.

Sumarto, Yonatan. ““'Suatu Tinjauan Terhadap Kejatuhan Manusia Ke Dalam Dosa Berdasarkan Kejadian Pasal 3.” Jurna Pasca Sarjana Nassakke (2021): 89-97.

Sung Wook Chung. Belajar Teologi Sistematika Dengan Mudah. Bandung: Visi Press, 2011. Susanto, Yusak Noven. "Pandangan Teologis Tentang Kehendak Bebas Manusia Dan Relevansinya Dengan Kehidupan Orang Percaya Saat Ini” (n.d.).

Syawal, H, and Helaluddin Helaluddin. "Psikoanalisis Sigmund Freud Dan Implikasinya Dalam Pendidikan.” March, 2018.

Tarpin, Tarpin. "Pandangan Kristen Tentang Dosa: Asal Muasal Dan Cara Menebusnya." Jurnal Ushuluddin 16, no. 2 (2010): 221-233.

Team Balai Pustaka. Kamus Besar Bahasa Indonesia. 3rd ed. Jakarta: Balai Pustaka Departemen Pendidikan Nasional, 2003.

Werner Gitt. Keajaiban Manusia. Jakarta: Yayasan Komunikasi Bina Kasih, 2009.

Yanjumseby Yeverson Manafe. "Keberdosaan Manusia Menurut Alkitab." Jurnal Scripta Teologi dan Pelayanan Kontekstual Vol.4, No. (2019): 111-131,.

"1 Tesalonika 5:23 (Versi Paralel) - Tampilan Ayat - Alkitab SABDA."

"Arti Kata Teologi - Kamus Besar Bahasa Indonesia (KBBI) Online."

"Hirarki Kebutuhan Manusia Menurut Abraham Maslow Dalam Perspektif Alkitabiah."

"Journal of Psychology \& Theology - Wikipedia."

"Page Not Found - Suara Injil." 